\title{
Hukuman dalam Pendidikan : Studi Komparatif Pemikiran Abdullah Nasih 'Ulwan dan B.F. Skinner
}

\author{
Ahmad Minan Zuhri \\ Universitas Muhammadiyah Yogyakarta \\ e-mail: amrymovich@gmail.com
}

\begin{abstract}
This study is based on the phenomenon of the cases number of punishment abuse in education. Punishment has become a favorite treatment chosen by teachers to control students, though not all educators choose it becomes habit. A discussion of punishment in order to educate the students, actually has been discussed several prominent Muslims and the West Islamic education Abdullah Nashih 'Ulwan, and the leaders of Western education for example B.F. Skinner. The education of the two figures, the authors tried to find out his thoughts about punishment in education. Furthermore, the authors compare these thoughts to determine the location of the similarities and differences, as well as the benefits and drawbacks. The results of this research are: 1) The idea of punishment in education according to Abd. Nasih 'Ulwan more emphasis on the moral requirements, while Skinner put more emphasis on human behavior; 2) Abd. Nashih 'Ulwan and Skinner do not agree with the punishment. The difference lies in the application of punishment in education. If Abd. Nashih 'Ulwan apply affectionate and gentle, while Skinner apply the principle of prudence.
\end{abstract}

Keywords: Punishment in education, Abdullah Nashih 'Ulwan, B.F. Skinner 


\section{Pendahuluan}

Pendidikan pada dasarnya bertujuan untuk mencerdaskan kehidupan bangsa dari kebodohan dan keterbelakangan. Guru dan siswa berperan dalam proses pembelajaran memiliki andil yang sangat penting untuk menciptakan suasana belajar yang kondusif. Usaha pendidikan untuk mengembangkan potensi kognitif, sikap dan keterampilan peserta didik maka pendidik atau tenaga kependidikan memikul tanggung jawab untuk membimbing, mengajar, dan melatih murid atas dasar normanorma yang berlaku baik norma agama, adat, hukum, ilmu dan kebiasaan-kebiasaan yang baik. Untuk mewujudkan tujuan itu, perlu ditanamkan sikap disiplin, tanggung jawab, berani, mawas diri, beriman, dan lain-lain.

Dewasa ini, sering terdengar berita tentang terjadinya kekerasan di sekolah yang justru dilakukan oleh oknum pendidik. Banyak masyarakat heran mengapa justru pendidik yang melakukan kekerasan. Sosok yang seharusnya dapat membimbing siswa-siswinya untuk mempunyai perilaku yang baik, justu memberikan contoh yang sebaliknya. Kekerasan yang terjadi, konon dilakukan dalam rangka menghukum peserta didik yang melakukan kesalahan. Namun, rasanya tidak ada satu pun peserta didik yang mau dihukum, padahal ketika norma yang telah disepakati dilanggar oleh peserta didik, hukuman yang bersifat mendidik (ta'zir) dalam belajar mengajar diperlukan untuk menjaga suasana belajar mengajar berjalan dengan baik.

Pada dasarnya, teori hukuman (punishment) merupakan salah satu metode yang digunakan untuk meningkatkan perilaku yang diinginkan dan mengurangi perilaku yang tidak diinginkan. Hukuman itu dimaksudkan sebagai upaya mendisiplinkan peserta didik terhadap peraturan yang berlaku. Sebab, dengan sadar pendidik memegang prinsip bahwa disiplin itu merupakan kunci sukses hari depan. Apakah bentuk-bentuk hukuman bisa dikembangkan untuk mendisiplinkan peserta didik? Pertanyaan seperti inilah menjadi dilema bagi kaum pendidik dalam mengemban kewajiban dan tanggungjawabnya. Dalam menciptakan kedisiplinan, pendidik harus benar-benar bisa sebagai suri tauladan bagi anak didiknya. Penerapan aturan hukuman bagi para siswa yang melanggar, tetapi tidak diikuti kedisiplinan pendidik, bagaikan "halilintar" di siang bolong, banyak yang menyepelekan. 
Penjelasan tersebut menunjukkan, dewasa ini metode menghukum (ta'zir) terhadap peserta didik sudah menjadi treatment favorit yang dipilih oleh pendidik untuk mengendalikan siswa, walau memang tidak semua guru memilih hal tersebut menjadi kebiasaannya. Keputusan tersebut biasanya menjadi ujung kebijakan guru setelah mengalami jalan buntu dalam menghadapi masalah siswa di kelasnya. Hal tersebut merupakan sesuatu hal yang "wajar", dan banyak pendidik yang memilih melakukan hukuman karena "mentok" atau sudah tidak menemukan jalan keluar. Allah SWT berfirman dalam Q.S. An-Nisa (4): 16, menjelaskan bahwa : "Dan terhadap dua orang yang melakukan perbuatan keji di antara kamu, Maka berilah hukuman kepada keduanya, Kemudian jika keduanya bertaubat dan memperbaiki diri, Maka biarkanlah mereka. Sesungguhnya Allah Maha Penerima Taubat lagi Maha Penyayang.” ( Departemen Agama, 2002: 104).

Selanjutnya, terdapat hadist riwayat Abu Dawud yang menggambarkan tentang metode hukuman, yaitu:

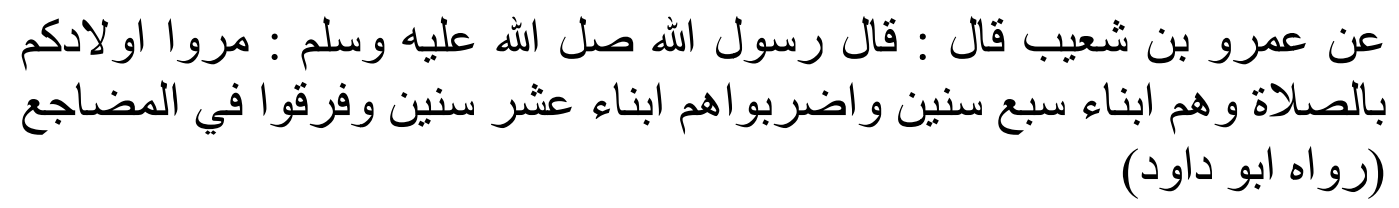

Artinya: "Suruhlah anak-anakmu untuk mengerjakan ia sholat ketika mereka (anakanakmu) berusia tujuh tahun, dan pukullah bila mereka membangkang (meninggalkan sholat) jika mereka telah berusia sepuluh tahun serta pisahkan tempat tidurnya." (H.R. Abu Dawud).

Dari sinilah dasar hukuman (ta'zir) dalam mendidik anak-anak dan juga orang dewasa menjadi sesuatu yang diperlukan, guna kepentingan mereka sendiri serta orang lain. Dalam pendidikan Islam, pembahasan tentang hukuman dalam rangka mendidik anak sebenarnya telah dibahas beberapa tokoh Islam, sebab hukuman dalam pendidikan itu termasuk dalam ruang lingkup pendidikan anak dalam Islam, yang dengan itu diharapkan terwujud pendidikan secara keseluruhan, yaitu kepribadian seseorang yang membuatnya menjadi insan kamil. Satu contoh tokoh pendidikan Islam yang membahas tentang pendidikan Islam misalnya Abdullah Nashih 'Ulwan. Beliau adalah salah satu pemikir pendidikan Islam yang concern terhadap pendidikan anak.

| Volume. 2, No. 1, Januari-Juni 2017 
Adapun pemikiran pendidikan di Barat yang membahas tentang hukuman dalam pendidikan mendapatkan tempat yang khusus dalam pembahasannya. Tokoh pendidikan anak dalam pandangan ilmuwan barat seperti J.J. Rousseau, Jhon Dewey, dan Burrhus Frederic Skinner merupakan ilmuwan Barat yang menjadi rujukan dan mendapat perhatian yang serius pada pendidikan anak, terutama masalah pendidikan fisik. Sebab pendidikan fisik ini yang akan mempengaruhi seberapa besar ketercapaian anak dalam proses pendidikan.

Misalnya, Burrhus Frederic Skinner atau lebih dikenal dengan B.F. Skinner adalah salah satu tokoh yang concern terhadap pendidikan anak. Skinner merupakan tokoh dibidang psikologi yang pada awalnya mendalami analisis eksperimental atas tingkah laku yang ia tempuh di Universitas Harvard. Skinner melakukan penyelidikan terutama pada organisme infrahuman, biasanya tikus atau merpati (Baharudin dan Nur Wahyuni, 2008: 66). Ia juga dikenal sebagai tokoh behavioris dengan pendekatan model instruksi langsung dan meyakini bahwa perilaku dikontrol melalui proses operant conditioning. Operant conditioning atau pengkondisian suatu operant yang dapat mengakibatkan perilaku tersebut terulang kembali atau menghilang sesuai dengan keinginan (Sugihartono, 2007: 97). Penjelasan tersebut memberikan gambaran bahwa, para tokoh pendidikan Barat memberikan perhatian yang khusus pada pendidikan fisik terutama yang berkaitan dengan permainan, kesukaan anak bahkan sampai hukuman fisik yang diterima anak, sebab ketercapaian pendidikan di Barat sangat dipengaruhi oleh bagaimana perhatian pada pendidikan fisik tersebut.

Dari penjelasan di atas tentang pemikiran pendidikan anak, termasuk di dalamnya hukuman dalam dunia pendidikan, baik di dunia Islam maupun Barat, merupakan hal yang sangat penting. Pendidikan pada masa kanak-kanak akan sangat menentukan kehidupan mereka di masa mendatang. Pemikir pendidikan anak di dunia Islam lebih cenderung bersifat filosofis-religius, sedangkan pemikir dari Barat cenderung pada sifat psikologis-akademis. Hal ini menarik untuk dicari benang merah yang dapat saling melengkapi satu sama lain, di mana pendidikan tidak hanya berdimensi filosofis-religius atau psikologis-akademis, melainkan paduan diantara keduanya yang mungkin dapat menjadi komprehensif. 
Berdasarkan uraian latar belakang masalah dapat dirumuskan masalah sebagai berikut : 1) Apa pemikiran Abdullah Nasih 'Ulwan dan B.F. Skinner tentang hukuman dalam pendidikan? 2) Apa persamaan dan perbedaan, serta kelebihan dan kekurangan pemikiran Abdullah Nasih 'Ulwan dan B.F. Skinner tentang hukuman dalam pendidikan?

\section{Konsep Hukuman dalam Pendidikan}

Hukuman sebagai salah satu teknik pengelolaan kelas sebenarnya masih terus menjadi bahan perdebatan. Akan tetapi apapun alasannya hukuman sebenarnya tetap diperlukan dalam keadaan sangat terpaksa, katakanlah semacam pintu darurat yang suatu saat mungkin diperlukan. Hukuman merupakan alat pendidikan represif, disebut juga alat pendidikan korektif, yaitu bertujuan untuk menyadarkan anak kembali pada hal- hal yang benar atau yang tertib.

Dalam bahasa Arab "hukuman" diistilahkan dengan 'iqab, jaza' dan 'uqubah". Kata "iqab” bisa juga berarti balasan. Al-Qur'an memakai kata "iqab" sebanyak 20 kali, Salah satunya terdapat pada Q.S. Ali Imran ayat 11, yaitu:

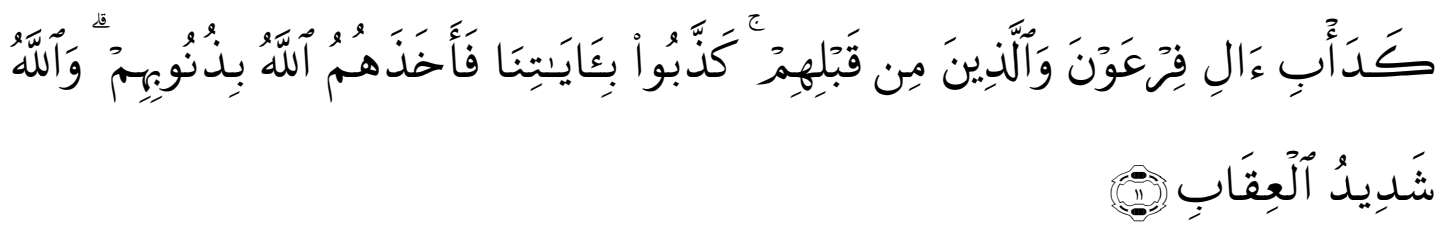

Artinya: "(keadaan mereka) adalah sebagai keadaan kaum Fir'aun dan orang-orang yang sebelumnya; mereka mendustakan ayat-ayat Kami; Karena itu Allah menyiksa mereka disebabkan dosa-dosa mereka. dan Allah sangat keras siksaNya. '(Departemen Agama, 1992: 76).

Bila memperhatikan ayat tersebut, terlihat bahwa "iqab" pada umumnya didahului oleh kata "syadid" (yang paling, amat dan sangat), dan kesemuanya menunjukkan arti keburukan dan azab yang menyedihkan. Dari ayat tersebut bisa dipahami, bahwa kata "iqab" ditujukan kepada balasan dosa sebagai akibat dari perbuatan jahat manusia. Istilah "iqab" sedikit berbeda dengan "tarhib", dimana "iqab" telah berbentuk aktivitas dalam memberikan hukuman seperti memukul, menampar, menonjok, danlain - lain. Sementara "tarhib" adalah berupa ancaman 
pada anak didik bila ia melakukan suatu tindakan yang menyalahi aturan (Maunah Binti, 2009: 113).

Menurut Amin Danien Indrakusuma (1973: 14) hukuman adalah tindakan yang dijatuhkan kepada anak secara sadar dan sengaja sehingga menimbulkan nestapa, dan dengan adanya nestapa itu anak akan menjadi sadar akan perbuatannya dan berjanji di dalam hatinya untuk tidak mengulanginya.

Menurut Suwarno (1992: 115) menghukum adalah memberikan atau mengadakan nestapa/penderitaan dengan sengaja kepada anak yang menjadi asuhan kita dengan maksud supaya penderitaan itu betul-betul dirasainya untuk menuju kearah perbaikan.

Fungsi hukuman bagi anak menurut kesepakatan para pakar pendidikan, setidaknya ada tiga, yaitu:

1. Fungsi restriktif, yaitu hukuman yang dapat menghalangi terulangnya kembali perilaku yang tidak diinginkan pada diri anak.

2. Fungsi pendidikan, yaitu hukuman yang diterima sebagai bentuk dari pengalaman yang dapat dijadikan sebagai pelajaran berharga.

3. Fungsi motivasi, yaitu hukuman yang dapat memperkuat motivasi anak untuk menghindarkan diri dari tingkah laku yang tidak diinginkan. (Yanuar A., 2012: 41).

Adapun kelebihan dan kekurangan hukuman, sebagai berikut: Pendekatan hukuman dinilai memiliki kelebihan apabila dijalankan dengan benar yaitu: hukuman akan menjadikan perbaikan-perbaikan terhadap kesalahan murid; murid tidak lagi melakukan kesalahan yang sama; dan merasakan akibat perbuatannya sehingga ia akan menghormati dirinya. Sementara kekurangannya adalah apabila hukuman yang diberikan tidak efektif, maka akan timbul beberapa kelemahan, antara lain: akan membangkitkan suasana rusuh, takut dan kurang percaya diri; murid akan merasa sempit hati, bersifat pemalas serta akan menyebabkan ia suka berdusta (karena takut dihukum); mengurangi keberanian anak untuk bertindak (Maunah Binti, 2009: 111).

Selanjutnya, syarat dalam pemberian hukuman yaitu : pemberian hukuman harus tetap dalam jalinan cinta, kasih dan sayang; harus didasarkan kepada alasan "keharusan"; harus menimbulkan kesan dihati anak; harus menimbulkan keinsyafan 
dan penyesalan kepada anak didik; dan diikuti dengan pemberian maaf dan harapan serta kepercayaan. Seiring dengan itu, Muhaimin dan Abd. Mujib menambahkan bahwa hukuman yang diberikan haruslah: mengandung makna edukasi; merupakan jalan/solusi terakhir dari beberapa pendekatan dan metode yang ada; dan diberikan setelah anak didik mencapai 10 tahun (Asma Hasan Fahmi, 1979: 135).

Prinsip dalam pemberian hukuman pun harus dipahami oleh seorang pendidik atau orang tua. Beberapa prinsip itu adalah : 1) Memberikan kepercayaan terlebih dahulu baru kemudian pemberian hukuman, 2) hukuman distandarkan pada perilaku, 3) menghukum tanpa emosi, 4) hukuman sudah disepakati, 5) adanya tahapan pemberian hukuman (Maunah Binti, 2009: 114).

Selain syarat dan prinsip, dalam pemberian hukuman, seorang pendidik atau orang tua pun harus paham berbagai macam bentuk hukuman, sebab hal tersebut merupakan pengaruh dari beberapa faktor yang memicu pembentukan hukuman itu terjadi. Perihal bentuk Hukuman, Soejono mengemukakan dengan tiga bentuk, yaitu:

1. Bentuk isyarat, usaha pembetulan kita lakukan dalam bentuk isyarat muka dan isyarat anggota badan lainnya.

2. Bentuk kata, isyarat dalam bentuk kata dapat berisi kata-kata teguran dan akhirnya kata-kata ancaman. Kalau perlu bentuk isyarat diganti dengan bentuk kata berupa kata-kata peringatan, menyebut nama anak yang nakal tadi dengan suara tegas.

3. Bentuk perbuatan, usaha pembetulan dalam bentuk perbuatan adalah lebih berat dari usaha sebelumnya.

Berkaitan dengan faktor yang mempengaruhi terjadinya bentuk-bentuk hukuman, Menurut Arini el-Ghaniy dalam Yanuar A. (2012: 41), setidaknya ada tujuh faktor pembentuk hukuman untuk anak yaitu : a) Usia, b) Jenis kelamin, c) Jenis kesalahan, d) Waktu dan tempat, e) Karakter orang tua/pendidik, f) Karakter anak, g) Tidak terlalu berat dan tidak terlalu ringan.

\section{Metode Penelitian}

Penelitian ini menggunakan pendekatan kualitatif teks atau disebut juga penelitian literatur. Analisis datanya menggunakan analisis interaktif bersumber dari 
teori-teori Abdullah Nasih 'Ulwan dan B.F Skinner. Data yang dihasilkan berupa data deskriptif berupa kata-kata tertulis yang disajikan secara naratif, dengan membandingkan pemikiran Abdullah Nasih 'Ulwan dan B.F Skinner dalam berbagai aspeknya.

\section{Hasil Penelitian}

\section{Pemikiran Abdullah Nasih Ulwan}

Dalam buku Tarbiyatul Aulad fil Islam jilid 2, Abdullah Nasih 'Ulwan (2008: 703) mengemukakan bagaimana metode yang dipakai Islam dalam upaya memberikan hukuman kepada anak. Sebagaimana diterangkan di bawah ini.

a. Bersikap lemah lembut adalah hal yang pokok dalam memperlakukan anak. Sebagaimana Bukhari dalam Adabul Mufrid meriwayatkan:

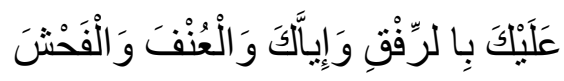

Artinya: "Hendaklah kamu bersikap lemah lembut, kasih saying, dan hindarilah sikap keras serta keji."

Selain itu, al-Harits, Ath-Thayalisi, dan al-Baihaqi meriwayatkan:

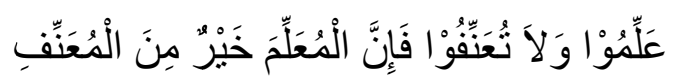

Artinya: "Ajarkanlah ilmu dan janganlah kalian bersikap keras, karena sesungguhnya pengajar ilmu lebih baik dari orang yang bersikap keras."

Dengan demikian, anak mendapat prioritas tersendiri dengan arahan nabawi ini kepada kelompok mereka yang harus mendapatkan pemeliharaan, kelemahlembutan, dan kasih sayang.

b. Memperhatikan karakter anak yang melakukan kesalahan dalam memberi hukuman.

$$
\begin{aligned}
& \text { الأولاد يتفاونون فيما بينهم ذكاء ومرونه واستجابة .. كما أن أمزجتهم تختلف على حسب } \\
& \text { الأشخاص ، فمنهم صاحب المزاج الهادئ المسالم ، ومنهم صاحب المزاج المعتدل ، ومنهم } \\
& \text { صاحب المزاج العصبي الشديد ـ وكل ذلك يعود إلى الوراثة ، وإلى مؤثرات البيئة وإلى العوامل } \\
& \text { النشأة والتربية . }
\end{aligned}
$$


Artinya: anak-anak mempunyai kecerdasan, kelincahan dan respon yang berbeda-beda,begitu juga pada wilayah karakter mereka. Ada anak yang berkarakter atau berwatak tenang, ada yang berwatak biasa-biasa saja, da nada yang berwatak keras. Semua itu tergantung pada faktor keluarga, pengaruh lingkungan, faktor-faktor tumbuh kembang, dan faktor pendidikan.

Anak-anak dilihat dari segi kecerdasan baik karakter maupun pemberian tanggapannya. Juga berbeda dari segi pembawaan, tergantung pada perbandingan masing-masing. Di antara mereka ada yang berpenampilan tenang, ada pula yang berpembawaan emosional dan keras. Semua itu tergantung pada keturunan, pengaruh lingkungan, faktor-faktor pertumbuhan, dan pendidikan.

Sebagian anak hanya cukup dengan menampilkan muka cemberut dalam melarang dan memperbaikinya. Anak lain, tidak bisa dengan cara itu, tetapi harus dengan kecaman. Bahkan terkadang pendidik perlu menggunakan tongkat untuk dihadiahkan kepada anak itu sebagai hukuman yang membuatnya jera.

Kesimpulannya bahwa, pendidik hendaknya bijaksana dalam mengunakan cara hukuman yang sesuai, tidak bertentangan dengan tingkat kecerdasan anak, pendidikan, dan pembawaannya. Di samping itu, hendaknya ia tidak segera menggunakan hukuman, kecuali menggunakan cara-cara lain. Hukuman adalah cara yang paling akhir.

c. Memberi hukuman secara bertahap, dari yang ringan sampai yang keras.

$$
\begin{aligned}
& \text { مما نؤهنا عنه قبل قليل أن العقوبة التي يجربها المربي للولد يجب أن تكون في مرحلتها الأخيرة ، } \\
& \text { ومعنى هذا أن هناك مراحل من المعالجة والتأديب يجب أن يمر عليها المربي قبل اللجوء إلى } \\
& \text { الضرب ؛ لعلها تؤدي الغرض في تقويم اعوجاج الطفل ، ولعلها تصلح من شأنه ، وترفع من } \\
& \text { مستواه الأخلاقي والاجتماعي ، وبتعله إنسانا سويا . }
\end{aligned}
$$

Artinya: Seperti yang baru saja kami jelaskan bahwa hukuman yang diberikan pendidik kepada anak harus diaplikasikan pada fase yang paling akhir. Artinya, terdapat beberapa fase yang harus dilakukan pendidik terlebih dahulu dalam memperbaiki dan mendidik sebelum mengaplikasikan hukuman. Misalnya memberi arahan kepada anak, memperbaiki tingkah lakunya, meningkatkan kualitas akhlak sosialnya, dan menjadiakannya manusia seutuhnya. 
Sebagaimana yang telah dijelaskan di atas, bahwa pendidikan dengan menggunakan hukuman adalah cara yang paling akhir. Hal ini berarti di sini seorang pendidik dapat menggunakan beberapa cara lain dalam memperbaiki dan mendidik. Salah satu caranya yaitu dengan memperlakukan anak sesuai dengan tabiat dan pembawaannya serta mencari faktor yang menyebabkan kesalahan. Hal ini akan membantu pendidik dalam upaya menyingkap sebab penyimpangan anak, agar ditemukan cara terbaik untuk memperbaikinya.

Adapun metode yang diberikan Rasulullah Saw tersebut, yaitu: 1) Menunjukkan kesalahan dengan mengarahkannya; 2) Menunjukkan kesalahan dengan sikap lemah lembut; 3) Menunjukkan kesalahan dengan isyarat; 4) Menunjukkan kesalahan dengan menegur; 5) Menunjukkan kesalahan dengan menjauhinya; 6) Menunjukkan kesalahan dengan memukul; dan 7) Menunjukkan kesalahan dengan hukuman yang dapat menyadarkan (Abdullah Nasih 'Ulwan, 2008: 706).

Pendidikan Islam sejatinya telah menjelaskan bagaimana menyikapi anak yang menyimpang atau melakukan kesalahan. Tahapan metode yang diberikan Rasullullah adalah bukti bahwa pendidikan Islam sangat serius dalam mengurusi masalah ini. Tahapan-tahapan metode yang diberikan Rasulullah bisa dipraktekkan seorang pendidik dalam mendidik anak-anak baik di rumah maupun sekolah, namun perlu di ingat, bahwa tahap pemberian pukulan yang dimaksud dalam penjelasan di atas ada batasan dan persyaratannya, sehingga pukulan itu tidak keluar dari maksud pendidikan, yaitu untuk memperbaiki dan membuat jera.

Adapun persyaratan memberikan hukuman pukulan adalah sebagai berikut:

1) Pendidik tidak terburu menggunakan pukulan, kecuali setelah menggunakan semua metode lembut, yang mendidik dan membuat jera, seperti telah diterangkan pada uraian sebelumnya.

2) Pendidik tidak memukul ketika dalam keadaan sangat marah, karena dikhawatirkan menimbulkan bahaya terhadap anak. Perlakuan ini 
merupakan realisasi wasiat Rasulullah Saw, "Janganlah kamu marah,maka surga bagimu, "sebagaimana yang riwayatkan oleh Bukhari.

3) Ketika memukul, hendaknya menghindari anggota badan yang peka, seperti kepala, muka, dan dan perut, sebab bagian-bagian tubuh ini sangat rawan yang dapat menyebabkan kefatalan.

4) Pukulan untuk hukuman, hendaknya tidak terlalu keras dan tidak menyakiti, pada kedua tangan atau kaki dengan tongkat yang tidak besar. Diharapkan pula, pukulan berkisar antara satu hingga tiga kali pada anak di bawah umur. Dan jika pada orang dewasa, setelah tiga pukulan tidak membuatnya jera, maka boleh ditambah hingga sepuluh kali.

5) Tidak memukul anak sebelum ia berusia sepuluh tahun, sebagaimana perintah Rasulullah Saw.

6) Jika kesalahan anak untuk pertama kalinya, hendaknya ia diberi kesempatan untuk bertaubat dari perbuatan yang telah dilakukan, member kesempatan untuk meminta maaf, dan diberi kelapangan untuk didekati seorang penengah, tanpa memberikan hukuman, tetapi mengambil janji untuk tidak mengulangi kesalahannya itu.

7) Pendidik hendaknya memukul anak dengan tangannya sendiri, dan tidak menyerahkan kepada saudara-saudaranya, atau teman-temannya. Sehingga, tidak timbul api kebencian dan kedengkian di antara mereka.

8) Jika anak sudah menginjak usia dewasa dan pendidik melihat bahwa pukulan sepuluh kali tidak membuatnya jera, maka boleh ia menambah dan mengulanginya, sehingga anak menjadi baik kembali.

\section{Pemikiran B.F. Skinner}

Dalam buku Science and Human Behavior, B.F. Skinner (2014: 182) mengemukakan bahwa:

"The commonest technique of control in modern life is punishment. The pattern is familiar: if a man does not behave as you wish, knock him down; if a child misbehaves, spank him; if the people of a country misbehave, bomb them. Legal and police systems are based upon such punishments as fines, flogging, incarceration, and hard labor. Religious control is exerted through penances, threats of excommunication, and consignment to hell-fire....." 
Kurang lebih Skinner mengemukakan bahwa teknik kontrol yang paling umum dalam kehidupan modern adalah hukuman. Polanya tidaklah asing; jika seseorang tidak berperilaku sebagaimana keinginan anda, jatuhkan saja dia; jika seorang anak berperilaku salah, tampar saja dia; jika warga sebuah Negara berperilaku salah, binasakan saja mereka. Sistem hukum didasarkan pada hukuman-hukuman seperti denda, cambuk, kurungan, dan kerja paksa. Kontrol keagamaan dijalankan melalui penebusan dosa, ancaman pengucilan, dan siksa api neraka.

Pendidikan tidak sepenuhnya meninggalkan tangkai pohon sebagai alat penghukum. Dalam hubungan personal setiap hari, dikontrol melalui sensor, cercaan, ketidaksetujuan, atau penyingkiran. Pendeknya, tingkatan sejauh mana seseorang menggunakan hukuman sebagai teknik kontrol tampaknya dibatasi oleh tingkatan sejauh mana seseorang mendapatkan kuasa yang diperlukan. Semua ini dilakukan dengan maksud mengurangi kecenderungan untuk berperilaku dengan cara-cara tertentu. Penguatan (reinforcement) membangun kecenderungan ini; hukuman didesain untuk meredam kecenderungan itu.

Ada beberapa efek samping dari hukuman yang disampaikan Skinner (2014: 184) pada bukunya yang berjudul Science and Human Behavior, antara lain sebagai berikut: Pertama, stimulus aversif (penguat negatif) yang digunakan dalam hukuman hanya terbatas pada situasi yang mendesak. Stimulus aversif digunakan sebagai langkah untuk menghentikan situasi yang tidak diinginkan dan pada kondisi yang mendesak, bisa memakai stimulus terkondisikan ataupun memakai stimulus tidak terkondisikan Misalnya, stimulus terkondisikan, ketika kita menegur anak dengan isyarat yang mengancam, respon yang didapat akan muncul seperti rasa takut. Adapun stimulus tidak terkondisikan yaitu ketika kita menghentikan seorang anak agar tidak bercanda di masjid dengan mencubitnya, cubitan ini akan mendapatkan respon yang cukup ampuh untuk menekannya. Tidaklah penting bagi efek-efek ini bahwa stimulus aversif menjadi tergantung pada perilaku-perilaku dalam urutan hukuman standar. Namun, ketika urutan 
tersebut diamati, efek-efek masih berlangsung dan harus dianggap sebagai salah satu hasil hukuman.

Kedua, pada umumnya, sebagai efek kedua hukuman, perilaku yang terus-menerus dihukum menjadi sumber stimulus terkondisikan yang membangkitkan perilaku yang tidak sesuai. Padahal maksud hukuman seharusnya memiliki efek yang mengikat. Diharapkan bahwa perubahan perilaku akan teramati di masa depan, meskipun hukuman lebih lanjut tidaklah diberikan. Ambil contoh misalnya, seorang anak secara konsisten dihukum karena berbohong. Perilaku itu tidak mudah ditentukan, karena respon verbal tidak dengan sendirinya pasti berarti sebuah kebohongan, baru dapat diartikan demikian dengan melihat pada keadaan yang melatarbelakanginya. Pada kondisi seperti inilah unsur utama dari apa yang disebut sebagai kesalahan, malu, atau dosa bangkit kembali dari perilaku yang dihukum berat tersebut.

Ketiga, setiap perilaku yang mengurangi stimulus aversif terkondisikan ini akan diperkuat. Dalam hal ini, Skinner uji coba pada seekor tikus, ketika tikus mendekati tuas tempat respon-responnya yang berlaku untuk dihukum, stimulus aversif terkondisikan yang kuat dihasilkan oleh semakin dekatnya tuas dan perilaku mendekat dari tikus itu sendiri. Setiap perilaku yang mengurangi stimulus iniberpaling atau menjauh, misalnyaakan mengalami penguatan. Efek hukuman dalam menetapkan perilaku yang bersaing dengan atau mungkin menggantikan respon-respon dihukum paling sering digambarkan dengan pernyataan individu menahan perilaku.

Hukuman berat tidak diragukan lagi memiliki efek cepat dalam mengurangi kecenderungan untuk bertindak dengan cara tertentu. Akan tetapi, dalam jangk panjang, hukuman tidaklah benar-benar menghapuskan perilaku dari repertoar, dan pencapaian sementaranya diperoleh dengan biaya yang sangat mahal dalam mengurangi seluruh efisiensi dan kebahagiaan kelompok.

Oleh karena itu, Skinner memberikan alternatif lain agar tidak ada hukuman pada suatu proses pendidikan anak. Hal ini bisa dihindari dengan cara melemahkan operan, misalnya karena sering kali cenderung dihukum, maka dapat dialihkan dengan cara dialihkan mengontrolnya melalui modifikasi 
keadaan. Cara lain untuk melemahkan respon terkondisikan adalah dengan membiarkan waktu berlalu. Proses melupakan ini tidak boleh disamakan dengan pemunahan. Sayangnya, proses ini umumnya berlangsung lambat dan juga mensyaratkan agar menghindari kejadian-kejadian yang menimbulkan perilaku.

Alternatif lain yaitu, dengan pemunahan (extinction), proses ini membutuhkan waktu lama tetapi lebih cepat daripada membiarkan respon agar dilupakan. Misalnya, ketika menganjurkan agar orang tua "tidak memberikan perhatian" pada perilaku tidak menyenangkan dari pihak anaknya. Jika perilaku anak kuat hanya karena telah diperkuat dengan "mendapat reaksi dari” orang tua, maka perilaku itu akan hilang ketika konsekuensi ini tidak lagi muncul.

Teknik lainnya, yaitu dengan mengkondisikan perilaku yang tidak sesuai, bukan dengan menarikcelaan atau kesalahan, tetapi melalui penguatan positif. metode ini digunakan ketika mengendalikan kecenderungan kearah ungkapan emosional dengan memperkuat perilaku sabar. Metode ini berbeda dari menghukum perilaku emosional, meskipun sebenarnya cara ini memberikan penguatan tidak langsung perilaku tabah melalui deprivasi stimulus aversif. Penguatan positif langsung itulah yang dipilih, karena tampaknya ia mempunyai produk samping yang tidak begitu merugikan.

\section{Perbadingan Pemikiran Abdullah Nasih 'Ulwan dan B.F. skinner tentang Hukuman dalam Pendidikan}

Berdasarkan konsep pemikiran kedua tokoh di atas, akan dapat diketahui point apa saja yang dapat disatukan, dan point apa saja yang dapat dihilangkan berdasarkan ketidakmanfaatannya dalam mendidik anak dengan baik dan benar, sehingga akan didapatkan suatu pemikiran baru yang dapat diaplikasikan dalam kehidupan seharihari sesuai dengan kombinasi konsep kedua pemikiran tokoh di atas. Sehingga akan ditemukan persamaan dan perbedaan, serta kelebihan dan kekurangan dari kedua pemikiran tokoh tersebut.

1. Persamaan pemikiran Abdullah Nasih 'Ulwan dan B.F. skinner tentang hukuman dalam pendidikan antara lain : 
a. Kedua tokoh tersebut tidak setuju dengan adanya hukuman. Hukuman alternatif terakhir dalam meluruskan dan memperbaiki kesalahan anak.

b. Nasih 'Ulwan cukup menunjukkan kesalahan anak dengan mengarahkannya, bersikap lemah lembut, member isyarat, menegur, atau menjauhinya, dan jika tidak membuahkan hasil barulah memberikan hukuman sesuai dengan kesalahannya. Skinner menggunakan metode penguatan negatif (negative reinforcement). Penguatan negatif ini menambah frekuensi dari kejadian perilaku yang diinginkan, di mana dapat menyebabkan pengakhiran atau penarikan dari beberapa kondisi yang tidak diinginkan.

2. Perbedaan pemikiran Abdullah Nasih 'Ulwan dan B.F. skinner tentang hukuman dalam pendidikan antara lain :

Terdapat perbedaan antara pemikiran Abdullah Nashih 'Ulwan dan B.F. Skinner dalam menerapkan hukuman dalam pendidikan. Abdullah Nashih 'Ulwan (2008: 703) berpandangan bahwa metode hukuman dapat menjadi metode alternatif dalam pendidikan anak, dengan catatan kasih sayang dan lemah lembut harus tercermin dalam sikap seorang pendidik dalam memberikan hukuman. Adapun cara yang diajarkan Islam dalam memberi hukuman kepada anak, yaitu: a) Bersikap lemah lembut; b) Memperhatikan karakter anak yang melakukan kesalahan; dan c) Memberi hukuman secara bertahap, dari yang ringan sampai yang keras.

Adapun B.F. Skinner memandang pendidikan dengan hukuman lebih hatihati dalam penerapannya, karena hukuman yang diikuti oleh anak tidak selamanya untuk perbaikan dan dorongan untuk maju, bahkan sebaliknya. Ada beberapa alasan mengapa B.F. Skinner tidak setuju dengan hukuman, yaitu: a) Pengaruh hukuman terhadap perubahan tingkah laku bersifat sangat sementara; b) Dampak psikologis yang buruk mungkin akan terkondisi (menjadi bagian dari jiwa si terhukum) bila hukuman berlangsung lama; c) hukuman mendorong si terhukum mencari cara lain (meskipun salah dan buruk) agar ia terbebas dari hukuman. Dengan kata lain, hukuman dapat mendorong si terhukum melakukan hal-hal lain yang kadang kala lebih buruk daripada kesalahan yang diperbuatnya. Oleh karena itu, pendidik harus menghindari hukuman, kecuali jika terpaksa dalam batas 
peraturan pendidikan. Misalnya, menghindari hukuman verbal maupun fisik, seperti: kata-kata kasar, ejekan, cubitan, jeweran yang justru akan berakibat buruk bagi anak didik.

3. Kelebihan pemikiran Abdullah Nashih 'Ulwan dan B.F. Skinner tentang hukuman dalam pendidikan.

Kelebihan pemikiran Abdullah Nashih 'Ulwan dan B.F. Skinner, pada dasarnya hampir sama, yaitu hukuman dilaksanakan hanya untuk mengontrol agar perilaku yang tidak pantas dapat berubah menjadi baik. Sehingga dalam penerapan hukuman digunakan seperlunya dan melalui cara tertentu. Perbedaannya, B.F. Skinner menggunakan cara-cara yang diperkenalkan oleh para orang tua dalam memberikan hukuman kepada anak, sedangkan Abdullah Nashih 'Ulwan menggunakan cara-cara yang diajarkan Islam dalam memberi hukuman kepada anak.

Abdullah Nashih 'Ulwan menyadari bahwa anak memiliki karakter yang berbeda satu sama lain, sehingga ketika hendak memberikan hukuman ia terlebih dahulu memperhatikan karakter anak tersebut, kemudian memilih cara yang sesuai untuk mendidik anak dan memperbaiki kesalahannya. Suatu waktu cukup dengan nasihat, pandangan tajam, kelemahlembutan, atau isyarat. Namun, jika hal ini tidak membuahkan hasil, barulah secara bertahap memberikan hal yang lebih keras dari sebelumnya, yaitu teguran. Jika teguran tidak bermanfaat, barulah memberi hukuman dengan pukulan yang tidak menyakitkan. Jika tidak berguna juga, maka barulah dengan pukulan yang menyakitkan, sesuai dengan syaratsyarat hukuman pukulan yang telah dijelaskan pada bab sebelumnya. Dan hukuman ini dilakukan di depan saudara atau teman-temannya. Agar hal itu menjadi peringatan juga bagi mereka.

Jika pendidik melihat bahwa anak setelah diberi hukuman telah membaik, maka pendidik harus mengubah sikapnya menjadi baik, lemah lembut, dan penuh senyum. Pendidik harus menunjukkan bahwa hukuman tersebut diberikan dengan tujuan demi kebaikan anak tersebut. Ketika anak merasakan bahwa pendidik setelah memberikan hukuman menjadi baik dan lemah lembut kepadanya, dan mengetahui maksud pendidik adalah untuk mendidik dan memperbaiki 
kesalahannya, maka ia tidak akan meresponnya dengan perasaan tertekan dan minder. Bahkan, ia akan menghargai perlakuan sayang pendidik dengan selayaknya dan memperbaiki kesalahannya, sehingga menjadi anak yang baik.

Selain itu, metode hukuman yang diperkenalkan B.F. Skinner memilki kelebihan lain, yaitu adanya penguatan positif. Penguatan positif merupakan penguatan yang akan mendorong anak untuk mengulangi tingkah laku sebelumnya. Tujuan pemberian penguatan positif adalah agar anak mampu melakukan pengulangan dalam hal ini akan berbuat atau berperilaku lebih baik. Misalnya, apabila ada anak didik menyapa guru kelasnya di jalan dengan cara yang sopan dan kemudian guru tersebut memberikan pujian kepada anak. Maka pada kesempatan ini, anak didik akan berbuat hal yang sama. Dengan demikian, pujian dari guru kelas merupakan penguatan positif dan perilaku anak didik merupakan reaksi atau respon. Sedangkan guru kelas yang sedang lewat di jalan merupakan perangsang atau stimulus, dan diberikannya pujian adalah akibat atau konsekuensi dari perilaku anak didik.

4. Kekurangan pemikiran Abdullah Nashih 'Ulwan dan B.F. Skinner tentang hukuman dalam pendidikan.

Kekurangan pemikiran Abdullah Nashih 'Ulwan tentang hukuman dalam pendidikan adalah, tidak adanya penguatan positif setelah pemberian hukuman. Padahal, penguatan positif diperlukan dalam upaya memperkuat sebuah tingkah laku yang lebih baik. Sedangkan kekurangan pemikiran B.F. Skinner tentang hukuman dalam pendidikan adalah, cara-cara pemberian hukuman yang diperkenalkan para orang tua di tiap daerah belum tentu sama, panduannya disesuaikan dengan budaya pembelajaran masing-masing daerah. Sehingga tidak memiliki panduan khusus tentang cara-cara pemberian hukuman kepada anak. Hal ini tentunya berbeda dengan Abdullah Nashih 'Ulwan yang menggunakan panduan khusus dalam memberikan hukuman kepada anak.

At.telume. 2, No. 1, Januari-Juni 2017 


\section{Kesimpulan}

Berdasarkan hasil penelitian, maka dapat disimpulkan sebagai berikut:

1. Pemikiran hukuman dalam pendidikan menurut Abdullah Nashih 'Ulwan lebih menekankan pada persyaratan moral, baik pada pendidik maupun anak didik, sedangkan B.F. Skinner lebih menekankan pada tingkah laku manusia.

2. Persamaan pemikiran Abdullah Nashih 'Ulwan dan B.F. Skinner tentang hukuman dalam pendidikan yaitu, keduanya tidak setuju dengan hukuman. Perbedaannya, terletak pada penerapan hukuman dalam pendidikan. Abdullah Nashih 'Ulwan menerapkan kasih sayang dan lemah lembut, sedangkan B.F. Skinner menerapkan asas kehati-hatian. Kelebihannya hampir sama, yaitu hukuman dilaksanakan hanya untuk mengontrol agar perilaku yang tidak pantas dapat berubah menjadi baik. Kekurangannya, dalam pemikiran Abdullah Nashih 'Ulwan, tidak ada penguatan positif setelah pemberian hukuman, sedangkan dalam pemikiran B.F. Skinner, tidak ada panduan khusus tentang cara-cara pemberian hukuman.

\section{Daftar Pustaka}

Baharudin dan Wahyuni, N. Teori Belajar dan Pembelajaran. Yogyakarta: Ar-Ruzz Media, 2008

Binti, M. Metodologi Pengajaran Agama Islam. Yogyakarta: Teras, 2009.

Departemen Agama, Al-Qur'an dan Terjemah. Surabaya: Mahkota, 2002.

Departemen Agama.Alquran dan Terjemah . Semarang: CV. Asy-Syifa', 1992.

Fahmi, A. H.Sejarah dan Filsafat Pendidikan Islam. Jakarta: Bulan Bintang, 1979.

Indrakusuma.A. D. Pengantar Ilmu Pengetahuan. Malang: Fakultas Ilmu Pendidikan IKIP Malang, 1973.

Rionaldi, A. "Tinjauan Yuridis Terhadap Kekerasan Yang Dilakukan Oknum Guru Terhadap Murid di Sekolah."Jurnal Fakultas Hukum Universitas Atma Jaya Yogyakarta, 2014.

Sugihartono. Psikologi Pendidikan. Yogyakarta: UNY Press, 2007.

Skinner, B. F. Science and Human Behavior. Pearson Education, Inc, 2014. 
Suwarno.Pengantar Ilmu Pendidikan. Jakarta: PT. Rineka Cipta, 1992.

'Ulwan, A. N. Tarbiyatul Aulad fil Islami. Jilid 2. Cet. ke-3. Kairo: Darussalam, 2008.

Undang-undang Sistem Pendidikan Nasional Nomor 20 Tahun 2003.

Yanuar A. Jenis-Jenis Hukuman Edukatif Untuk Anak SD. Yogyakarta: Diva Press, 2012. 
68 Ahmad Minan Zuhri

Hukuman dalam Pendidikan : Studi Komparatif Pemikiran Abdullah Nasih 'Ulwan dan B.F. Skinner

| Volume. 2, No. 1, Januari - Juni 2017 